\title{
THE COURSE IN CLASSICAL CULTURE AT FORT HARE
}

In Akroterion of June 1993 Prof. Lambert dealt with the various approaches and strategies which could be followed in the teaching of Classical Culture courses. In Akroterion of April 1994 Prof. Conradie stated that it would be valuable if Universities could exchange information about the content of such courses since there are a number of problems in their design. To mention a few problem areas that both articles refer to:

* The comprehensive nature of the material which tends to make such courses too extensive

* The correct "mix" of the course, i.e. steering between the Scylla of superficiality if a complete chronological, historical survey is attempted, and the Charybdis of the loss of perspective and context if only a thematic approach is followed

* The development of a meaningful and academically justifiable course that is attractive and interesting to students (FTEs in SAPSE terms!)

* Relevance, contextualisation and Eurocentricity

At Fort Hare such problems have a special poignancy and there are additional factors to consider. Here are a few:

* In an article "Die kosmologiese krisis in Swart verstedeliking en transkulturele ontwikkeling in SA", in the SA Journal of Ethnology 15.2 (1992), J.S. Malan discusses what he calls "... the transcultural clashing of interests ... within the framework of the fundamental polarity between the African and Western cosmologies." Some of his assumptions and conclusions are arguable, but he does illustrate that there is a significant cleavage between these different world-views and life views.

* Students generally do not rate Classical studies highly because they regard them as having no immediate vocational value. Such studies as a viable, meaningful, relevant and formative endeavour are often written off as not productive in bread-and-butter terms. We need to overcome this prejudice and open up the rich classical cultural heritage as a new avenue of experience for a society in transition, a society that is constantly developing more sophisticated and specialized needs in the Humanities.

* The under-preparedness of most students due to poor schooling needs no elaboration. In the general background and experience of the students there is little to acquaint them with the world of learning, let alone with the Classical world many of them come from homes where there are no or only a few books. About the only context in which the Classics feature is the expression: "It is Greek to me"!

* Classical Culture is a one-year course only. In spite of extensive recruitment drives to increase enrolment in the course, we have never had more than 18 students for Classical Culture. For such and other reasons (e.g. the composition of their curricula), the extension of the course to second and third year level is not deemed 
viable. Classical Culture is offered this year for the first time at our Division of External Studies at Bisho and the difference in dealing with more mature students, many of them with e.g. teaching diplomas, is quite noticeable and gratifying.

* Classical Culture is a compulsory ancillary for the B.Ped degree with English as a major and a number of students take it for this reason only. For such a captive audience, it is especially difficult to inspire enthusiasm and make the study a worthwhile and meaningful experience.

* As the Department has only two staff members, it is a difficult task to be responsible for all the aspects of the Classical Culture course, in addition to the Greek and Latin courses.

* For a number of years (the "new" Fort Hare was born 4 years before the "new" SA) our University has been engaged in Strategic Planning exercises (i.e. Reconstruction and Development plans). This also necessitated a heartsearching investigation into the role of the Department in the Fort Hare context.

* We have found it necessary to compile extensive study manuals: most students have poor study skills and need maximum assistance when faced with a large amount of unfamiliar work.

Against this background and over a number of years of teaching the course, some considerations, guidelines and criteria gradually crystallised, which resulted in the present form of the Classical Culture course. A few of these are mentioned:

An extract from the Department's Strategic Planning documents: The Instructional Mission of the University is to seek to acquaint students through the curriculum with the tradition of human values and their heritage and through that to develop life-long skills of critical thinking, articulate expression and independent living and learning. The Department fully identifies itself with this mission and is well positioned to achieve it. Classical studies should lead to e.g.:

* An extension of intellectual and cultural horizons by discovering the world of the Greek and Roman ages and its legacy.

* A broad cultural enrichment and a better insight into language, civilisation, history, humanity and cultures whose expectations, values and attitudes reflect many of our own.

* A perspective upon many facets of present-day civilisation and cultural variations.

* Some understanding of the world they live in by comparing it with a different cultural milieu, thereby developing self-knowledge, critical awareness and tolerance.

As an introduction to the course, a broad historical, chronological survey to give the student some general background and to provide a framework where other topics should be fitted in, was found necessary. A number of other topics dealing only with certain aspects of the Classical world are to be selected, the criteria for selection mostly intrinsic value, relevance and continuity. (Naturally personal preference and expertise also play a role.) These topics are to be dealt with in a more thematic way, with more emphasis on community factors and cultural aspects like statecraft, education, religion and literature than on political and military events; more on general ideas and characteristics than on details or specialised topics. The topics should also deal with problems that are still current e.g. democracy, reform. control of political power, land distribution, violence, clash and 
fusion of different cultures, literary and artistic theory, values in education - the list is endless.

Years ago Prof. Viljoen (Akroterion, June 1980:2) summarized the uniqueness and excellence of the study of the Classics in four cardinal points:

* $\quad$ "... Klassieke studie (wentel) ... deurgaans om sentrale vraagstukke van intrinsieke, fundamentele en blywende belang wat vir alle tye en plekke groot betekenis het."

* Dit omvat "alle betekenisvolle aspekte van die lewe en kultuur in daardie tyd. Dit verteenwoordig 'n meer omvattende en ensiklopediese beskouing van die hele lewe...

* Die Klassieke bied "die voordeel van 'n afgeslote, voltooide studie-objek, wat 'n deeglike en indringende ontleding moontlik maak en ook 'n sekere stabiliteit, sekerheid bied in 'n lewe van verbysterende snelle verandering ..."

* $\quad$ "... die historiese verloop van die Klassieke wetenskapsbeoefening in sigself (bied) 'n boeiende panorama van perspektiefverskuiwings deur die eeue en dekades heen..."

It is impossible to capitalise fully on the excellence and uniqueness of Classical studies in a one-year teaching course, but it is very useful to keep in mind when study topics are selected and worked out.

The question of Eurocentricity and contextualisation - the relevance and value of Classical Culture in the new SA - remains intricate. This discussion will be limited mainly to how it relates to the specific course at Fort Hare. The bulk of the course is - and can only be Eurocentric in nature. Naturally parallels, similarities, affinities and resemblances with the present SA could be stressed. (One should however be cautious in view of the danger of slanting: during the height of violence in SA one could put e.g. the Peloponnesian War on a Procrustean bed.)

Direct connections and influence, however, after one has dealt with matters such as Roman-Dutch law, are not easy to find. Afro-Asiatic influences a la Black Athena or links with Roman Africa, due to their remoteness in time and space, do not really make the course more indigenous in the eyes of the students. A Nigerian Oedipus a la Conradie (Akroterion, April 1994) qualifies much better: it is just a pity that we cannot point to such direct links amongst Black South African writers - to the best of my knowledge there are none. Even in authors like Tamsanqa, Mtywaku and Peteni the influence is at most Shakespearean. Peteni's KwaZidenge, for instance, is generally regarded as an African version of Romeo and Juliet. Mofokeng's Senkatana only reminds one of the ancient Greek tragedy and has characteristics that resemble classical drama. We do not (yet) have a Demea, not by a Guy Butler from a Western background, but by a Black South African author from an African background.

Comparative studies of Graeco-Roman and African religious ritual, myth and social custom (cf. a Zulu Demeter a la Lambert - Akroterion, June 1990), attempts to unravel a deep kinship between ancient Greece and modern Africa etc., are interesting and valuable, but cannot really be accommodated in an already full one-year Classical Culture course. This course, dealing basically with the Classical world, should be the foundation of subsequent comparative studies. The avenue of inter-disciplinary studies should also be exploited: The Department of English at Fort Hare recently became the Department of English Studies and Comparative Literature and included in the new syllabi are surveys of the history, themes and forms of Classical Literature.

In any case, 1 believe that the value and relevance of the Classical Culture course in the present SA do depend on the ability to find a proliferation of direct connections, explicit 
influences and analogies or even on making meaningful comparisons. I do not think that it is necessary to search frantically for such items to justify the course or to Africanise it to the extent of artificiality. Courses in Anthropology also have to explain "foreign cultures" to students. The so-called "New Ethnography" or "Ethnosemantics" proposes that a culture should be understood as someone who lives in it would experience it (the insider view, emic perspective), and not as a foreigner would see it (outsider view, etic perspective) - in other words, you see and understand a community or a culture as an aborigine and not in externally created terms or categories. Perhaps we could take a page also from this book.

A one-year course in Classical Culture should deal with study material that is worthwile in its own right (see Viljoen above), even if it is essentially Eurocentric. It deals with one of the most fundamental, formative and significant periods of human history and culture with a lasting influence, also in SA, on most aspects of the modern world - "Griechen sind wir im innersten Herzen immer." This continuity and legacy, also through the processes of acculturation, adaptation and fusion, should be stressed. Generally valid dimensions, universal and timeless elements, the common bonds of humanity, and Greek and Roman responses to questions that are still topical today, should be brought out. To put it in our Nestor, Haarhoff's, words (Lantern, September 1959): "..select those events that show us how the past contributed or could contribute to our present experience and ... in making this selection we should try to eliminate what is merely conventional or accidental and find, if possible, a universal principle. We must try and see how far man at a particular point has succeeded in being civilized, stumbling along in his blinded way and obsessed with his 'homesickness for the mud,' as the French say." A paternalistic attitude of the superiority of Classical or Western culture, as if it is the canonical measure of all things, and a Graeco-Roman puristic view should be avoided at all costs.

All the above considerations, a process of trial and error and often a Hobson's choice led to the present course. It has been divided into 22 topics/study units:

* The continuity of the classical civilisation and its heritage;

* In both the Greek and Roman sections: Introduction, background and survey of the civilisation and its history; Religion; Education; Literature; Art and Architecture;

* The polis; Athenian democracy; Socrates: Ápology; The Delian League; The Peloponnesian War; Alexander's empire;

* The Roman Republic: constitutional and social developments: Epic poetry; Roman slavery; The Augustan principate; The Roman legal system.

The material is still (too) comprehensive, but we also concentrate each year on a number of topics within this framework e.g. Greek tragedy, Eleusinian mysteries, the Sophists, Pericles' Funeral Oration etc.

Extensive manuals (about 300 pages in total) were compiled and each of the manuals for Greek and Roman culture consists of two parts:

* Part I: Outlines/synopses/summaries of the study units/topics, with references to Part II. Surveyability and orientation are the main purposes of this part.

* Part II: Maps, time charts and extracts from primary and secondary sources including "modern" material like an imaginary interview with Socrates.

To get enough students to take and enjoy the course and to attain aims such as insight, critical thinking, a breadth of vision, a historical perspective, the creation of interest in the 
Classics in the community we serve etc. - in short fulfil what the Department set as its mission - remains difficult. It is a task worthy of Heracles - not of Sisyphus, I hope. I have no illusions that the Classical Culture course at Fort Hare has reached the ideal solution, but it is an attempt in this direction under many restrictive parameters.

J.M. Els

\section{CURRICULA NOVISSIMA}

The Department of Classics at U.C.T. has introduced a one semester course on Greek Mythology which is aimed at students from any faculty. The course, entitled, "Ancient Mythology" (CLA209F) covers theories on the origins of myth, the most common stories, and the continued influence of myth in modern life, literature and art. It is open to anyone in any faculty, post-first year. Faculties differ, but it offers two credit points towards degrees in the Faculties of Social Science and Humanities.

By die Universiteit Stellenbosch word - op versoek van die Fakulteit Regsgeleerdheid - 'n nuwe tweejarige kursus ingestel veral met die oog op regstudente. "Klassieke Regskultuur $144^{\prime \prime}$ is 'n eerste semester-inleiding tot die geskiedenis van Romeinse regskepping en regsontwikkeling, Latynse regsterminologie asook eenvoudige beginsels van Latyn, met klem op sy invloed op Engelse en Afrikaanse woordeskat.

In die tweede helfte van die eerste jaar sal variante modules (144 of 154) of op taalinleiding konsentreer (wat met bykomende studie tot Latyn II kan lei), of op voortgesette regsagtergrond en -terminologie en die gebruik van Romeinse en Hollandse regsbronne in Suid-Afrikaanse hofsake. In die tweede jaar van Klassieke Regskultuur (278) sal studente opleiding ontvang in die beginsels en praktyk van retoriek en dialektiek en ook in die antieke hantering van regsvraagstukke soos die posisie van vrou, kind en nasciturus, slawerny, Afrika en die antieke wêreld, en die oorspronge van demokratiese denke.

Another new course at Stellenbosch, now entering its second year of implementation, is a two year modular taught MA course, aimed at students with any Bachelor's degree. During 1994 the modules were "Ancient historiography" and "Africa in antiquity". Stellenbosch was fortunate in being able to share the services of U.C.T.'s guest lecturer, Professor J.A. Ilevbare from Ibadan. The 1995 modules will be "Epic" and "The clash of religions in the ancient world".

\section{J.M. Claassen}

